\title{
Too far West (dangerous curves ahead)
}

\author{
Will Visconti \\ The University of Sydney, Australia \\ will.visconti@sydney.edu.au
}

\begin{abstract}
In a career that lasted over eighty years, the performances of Mae West were famous, or infamous, for their power to shock, their transgression of boundaries of class, gender, sexuality and propriety, and for the frequent opprobrium that West seemed to attract. Moreover, there was no subject matter considered "off-limits" within Mae West's work, and her plays and films were marked by her fearless approach to topics that even today are often seen as problematic (substance abuse, abortion, rape, and the idea of the "expiry date" of the female performer and her sexuality). West also broke new ground by both bringing taboo subjects into mainstream view, and by combining a sympathetic and humorous treatment of serious topics. Despite her reputation as a screen icon with a rapier wit, her work as a writer, and indeed, the effort she put into creating and maintaining the style and content of her act is frequently overlooked. Throughout her plays, films, radio appearances and written work, she consistently pushed the envelope in terms of what was deemed acceptable, normal or humorous for her age (and her era). When castigated for going "too far", she simply edited her material and tried again, inching forward and gradually setting a precedent for later generations of comics and comic writers, while situating herself within an extant framework of shocking and subversive performers. This paper is intended as an exploration not only of West's much-publicised transgressive use of humour, or the subversiveness of her humour itself, but also the way in which her career trajectory embodied the notion of going "too far" with her final films, and how Mae West's life so frequently imitated her art.
\end{abstract}

Keywords: Mae West, transgression, sexuality, film, female comedy.

\section{Introduction}

In a career that began in the final years of the nineteenth century and lasted until 1978, Mae West became renowned for pushing the boundaries of propriety, class, race and most famously sexuality and gender in her work as a singer-writer-dancer-actor who performed in film, television, theatre, vaudeville, burlesque and radio - invariably shocking and entertaining in equal measure by "mingling the comic and the erotic" (Wortis Leider 1997: 
11). West made a name for herself in vaudeville, revue and theatrical performances by going further than her contemporaries - be it in terms of her larger-than-life persona, the over-thetop nature of her acts, or her representation of taboo subjects. This article looks at Mae West's oeuvre thematically rather than strictly chronologically. One reason for this, beyond the length of West's career as a performer, is because many of the gags developed and incorporated into the Mae West Character (as Mae West herself saw it, divorcing herself from her persona onstage or behind-the-scenes, and seeing herself in the third person as a performer) are in fact repeated across media (Riva 1994: 151-152; Southwell 2002; Louvish 2006: 56). West, despite going too far with risqué humour and challenging subject matter, also fell into certain habits as a performer, and once she struck a winning formula as she did with the creation of the character and the play Diamond Lil, she would maintain and replicate it while simultaneously pushing boundaries in terms of representation and delivery of subject matter.

What one must remember about Mae West is that she was made, not born. She was shaped by her own process of crafting and maintaining her own image, at times by citing other performers or trends as reference points, or with the help of figures like her mother Matilda, who first pushed her to perform and was her most ardent supporter (Wortis Leider 1997: 20). Contrary to the stories (often of her own making) that told of her sexual conquests and nights spent with a string of lovers, West devoted time instead to honing and redrafting jokes, teasing out punch lines and reworking her quips and epigrams for maximum impact, so that what appeared effortlessly witty was frequently born of an off-the-cuff idea or joke and subsequently refined with careful practice and editing (Louvish 2006: xvi). In addition to being something of a magpie in terms of constructing her public image, the Mae West Character was already closely intertwined with her offstage persona, and certainly became even more fused as time progressed and she established herself effectively as Diamond Lil all her life. Regardless of the fixity of the nature of the Mae West Character, West reinvented herself as a writer and capable performer across media and genres including vaudeville, burlesque, film, radio and rock'n'roll. As a result of fusing varied styles and aspects of performers and acts with which she was familiar, her style and delivery set her apart. It was this brash, unapologetic and perennially tongue-in-cheek character that took extant material further, and for longer, than other performers of her age and milieu.

In the process of creating and refining the nature of the Mae West Character, she foregrounded her affinity with marginalised groups and subcultures, most noticeably black and gay music and culture, from which she appropriated elements for use in her own act, be it subject matter, mannerisms or style. By adapting these disparate elements and presenting them through film, television, stage performances, songs and radio spots, she brought the original subcultures into the mainstream and more inescapably in the public eye with the dual purpose of arguing in favour of disenfranchised demographics while complementing her own image (Robertson 1993: 20). A further part of this process was the granting of a greater degree of agency to these same groups, and making them the actors rather than the butts or victims of jokes. West went too far not only in terms of her jokes, for which she is most famous, but her behaviour more generally -creating further blurring between Mae West and the Mae West Character- and her attitudes towards women, homosexuals, and nonCaucasians were seen as beyond the pale.

Mae West was perceived as going too far in her humour because of two key factors: her staunch refusal to cede to boundaries of bourgeois morality and censorship - or indeed any rules but her own. This was particularly problematic during her film career because of the climate of the industry under the "Hays Code" (named for its architect, Will Hays), designed to remove material from motion pictures that was deemed to be questionable. Added to West's stubbornness was the fact that she enjoyed the controversy created by her work, 
revelling in the scandal and resultant publicity (Curry 1991: 74). The themes addressed here fall into the broad categories of sex and sexuality, gender, race, and age, though some overlap exists between these categories. However, neither the repercussions of West's flouting of censorship laws nor the resultant trials for obscenity will be specifically dealt with here. Rather, the focus is (to paraphrase West herself) on what she did and how she did it, what she said and how she said it, and how she looked when she did it and said it (Chandler 2009: 19).

\section{Sex ("I feel like a million tonight... but one at a time")}

One of the ways in which Mae West went "too far" with her act was by the simple fact of making a joke about, or of, sex. Unlike the predatory and ultimately punished femmes fatales of early cinema and melodrama (of whom the silent screen "vamp" Theda Bara is the most famous example), Mae was sexually assertive but not deliberately destructive. The perceived threat posed by West and the Mae West Character lay partly in her control of the situation, but also in her irreverence and her sexuality being closer to that of a man of the period; that is, taking lovers as it pleased her, on her own terms, and by rejecting traditional stereotypes of marriage and maternity. This is seen in many of West's plays and films, in which her character has multiple suitors and often more than one offer of marriage - beginning with the first known piece penned by Mae in 1921, a play entitled The Ruby Ring, in which an early Mae West Character makes a bet with a friend to get five marriage proposals in "less than five minutes each" (Louvish 2006: 85, 89). The trend is continued in She Done Him Wrong (Sherman 1933), Klondike Annie (Walsh 1936) and Sextette (Hughes 1978; in which the sextet in question is comprised of the husbands of Marlo Manners, played by Mae West).

West's work and style of performance were described as both traditional and burlesque, or less ambiguously as a burlesque of burlesque (Troy 1933: 547-558; Robertson 1996: 27-28). In point of fact, much of her act was a composite of other performers who were seen as transgressive in their own right - singers like Sophie Tucker and Eva Tanguay, female impersonators like Bert Savoy and Julian Eltinge, and even to a comedian Bert Williams and hostess Texas Guinan, most of whom were friends or acquaintances. West made sure to pay attention to trends and current performers either as sources of inspiration, or in order to gain an understanding of her competition and therefore amend her act in order to offer something else. It was because of Clara Bow's act, for example, that Mae altered her script for a play originally entitled Following the Fleet, with the final product eventually morphing into Sex (Schlissel 1997: 6). However, the key point of difference between Mae West and other performers, particularly female performers, was how much further West went in her characterisations or her use of humour. Eva Tanguay, for instance, defused her sexual appeal by playing up the madness and abandon of her act, appearing ludicrous but not lewd uncontrollable but less threatening; similarly, Sophie Tucker's age and weight undercut her transgressive potential and made her appear to be less of a threat in her sensuality (Hamilton 1995: 34; Wortis Leider 1997: 149). Tucker also created a persona who could be interpreted as both more comic and less threatening in her sexuality by marketing herself as "the Last of the Red Hot Mamas", in contrast to the distinctly un-maternal Mae West.

Mae West played up the sensuality of her songs and took them from cheeky to naughty through her delivery of lyrics; she exaggerated the already overplayed femininity of drag actors in her own onstage style, and drew from the musical repertoire of vaudeville and blackface or jazz numbers to combine with variations on trends of the moments like the cooch dance or the shimmy shawobble (a provocative dance popularised by burlesque performers and dancers in black-and-tan bars) in an effort to create a new, innovative (profitable) act (Watts 2001: 49, 194, 278). It can be argued that she also used jokes about her 
views and attitudes to undercut their shocking nature and/or to defuse tension. If she made a quip about black people or gays, it could all be argued away as part of the act, and seen as less subversive (or potentially masking the subversiveness of what she was doing). This would emphasise the ambiguity of her humour and toy with the audience or censors' perception of the real meaning of the text's comedy (Hamilton 1992: 82; Wortis Leider 1997: 174). Certainly, she admitted that at times when she was forced to tone down the content, she relied on humour and increased comedic elements to compensate for the alteration to her work.

When faced with censorship in film, West always claimed that she created "decoy" material to fool whoever was reading the script (West 1975: 3-4; Ashby 2006: 230). She maintained that she was able to sneak jokes and certain references or material into the movie that could be easily enhanced or downplayed by altering a line's delivery, or timing. West was certainly not alone in this strategy, with others like the "Queen of Music-Hall", Marie Lloyd, famously singing "clean" versions of songs when she knew that she was under scrutiny (Macqueen-Pope 1957/2010: 73; Carmichael \& Nuttall 1977: 34, 68-69, 140-141).

In a sense, however, and certainly from a point of view that Mae West herself would have argued (and indeed most likely did when her plays were raided by the police and she faced charges for obscenity), her jokes did not in fact go very far at all. The reliance on delivery and innuendo was a staple of vaudeville and burlesque humour, and her language was that of the street and the speakeasy (Schlissel 1997: 8). Another integral part to the construction of her persona was the "Tough Girl": a "type" found in the Bowery (a rough New York neighbourhood known for its slums, brothels, crime and saloons) in the late 1800s, who embodied more of a brash, working-class personality than the Gibson Girl (Chauncey 1994: 61; Hamilton 1995: 10-12). The Tough Girl was invoked in a way that created parallels with the twentieth-century Flapper, and highlighted West's origins as a New Yorker. Moreover, West's thick Brooklyn accent permeated the roles she took, regardless of the setting (be it New Orleans, New York or Alaska), and further highlighted her background to her audience.

As well as overstepping bounds of decency with her bawdiness, West did not shy away from taking on subject matter that was seen as unsavoury; moreover, she kept the unsavoury elements (at least in her plays). Productions of her plays Sex, The Drag and The Pleasure Man, all launched in the 1920s, offered unvarnished depictions of prostitution, suicide, drug use, date rape, abortion, sex trafficking and homosexuality (see Schlissel 1997). By the time the plays were made into movies, or provided the basis for West's films during the 1930s, the Hays Code had removed and softened the hard-hitting aspects of West's material, and diluted the chances for humour as much as for social commentary or realism. In cases like this, Mae West later said that when faced with circumstances where she had to remove content deemed objectionable, she replaced it by increasing the comic scenes (Merryman 1969: 62d, quoted in Wortis Leider 1997: 540). This had the added benefit of augmenting what remained - knowing that censorship had deprived the audience of material enhanced their reactions and they then sought innuendo and gags throughout, with the threat of censorship enhancing or yielding subsequent jokes (Curry 1996: 81; Failler 2005: 100).

Even though what is most remembered is West's reputation for overstepping the bounds of decency or normalcy in performance and in her private life, it can be equally argued that in some instances she did not go far enough. In her own written work, her characters often end up maintaining the status quo in one way or another, albeit with some ambiguity. Take for instance Margy LaMont in Sex. At the play's end she proves her moral superiority over her snooty wealthy antagonist, and has an offer of marriage from a wealthy man (West, Sex, Act III, Scene 2). However, rather than turn Sex into a Cinderella story, LaMont spurns the offer for the sake of her lover, and leaves for Australia, to make her own 
fortune and create a new life for herself. The rejection of marriage could be seen as shocking, yet it is couched in terms of social respectability (something repeated in films like Klondike Annie; Walsh 1936). Furthermore, whenever the Mae West Character does not marry or have a relationship it is by her choice, and it is the Mae West Character who is in complete control.

What is also interesting is precisely what Mae West's characters did, or rather, did not do and receive recognition for. Susan Glenn (2000: 107) points out that her characters were only ever desired for their looks - not the other skills with which her characters were endowed, such as business sense, wit, savvy, or even earning potential. This raises the question of why West never created characters who were more desirable beyond a physical sense, which could have served as an even more subversive idea in film in the early 1900s and a potentially well-timed one in the inter-war years.

\section{Gender ("The curve is more powerful than the sword")}

When discussing gender in Mae West's life and work, one must first recognise an overarching fact: she was most often the sole woman and the sole focus. It could be suggested that she decided against male co-stars who might outshine her, but certainly in terms of female characters, there are few present beyond maids or rivals, whereas male admirers are in abundance.

West consistently played with, challenged and pushed the envelope regarding gender, be it in a sexual or social sense. Nevertheless, her work was seen as confronting because she brought urban subcultures into mainstream view and challenged attitudes towards gender and sexuality by showing alternatives without condemnation. West roundly contradicts common tropes such as the punishment of the "fallen woman" and the villainy or degeneracy of the homosexual, and not merely playing up stereotypes for laughs (Finney 2005: 59, 63). In so doing she was seen as championing a "perverted" subculture, but broke with "status quo domesticity" and maintained the reputation she held in her private life with her characters: Mae West always triumphs (Finney 2005: 64). Another way she does this is by making the eponymous queens of her play The Drag the sympathetic characters both for viewers and in terms of interactions between characters, something that has only reached mainstream media in recent years, and challenging class biases (though she just as often includes caricatures of ethnic and cultural comic "types" in her work, particularly throughout The Pleasure Man, the opening scene of which is a bawdy, fiery dialogue between Irish scrubwomen).

It is the "girls" like the female impersonator Bird of Paradise Dupont who are the voice of morality in the plays and come to the aid of Mary Ann, the pregnant (and then attacked) victim of Terrill, the pleasure man. Judith Butler has suggested that drag has potential as politically subversive, and therefore by combining drag with a sympathetic representation, Mae subverts prevailing notions of gender, masculinity and virtue (Butler 1990: 174-175). In addition to the presence of homosexuals, drag queens, drug addicts and assault victims in The Pleasure Man (Schlissel 1997: 143-200), another shocking element of the piece is the implied fate of its eponymous character, Terrill, in the final scene. Again, the details are not made explicit, but enough is said to infer that Terrill's murder was the result of a fatal castration performed as an act of retribution by the brother of a woman whom he "used for [his] dirty sport" (West, The Pleasure Man, Act II, Scene 3).

For the casting of The Drag, Mae hand-picked numerous drag queens and clients from gay bars and night-spots in New York in order to convincingly depict the burgeoning gay subculture of the city, and to act as extras in a drag ball that occupies almost a whole act; she had also attended drag shows and handed out free passes to patrons to publicise Sex (Watts 2001: 82). During these scenes she encouraged the performers to ad-lib their lines to better 
recreate the atmosphere of the venues where they normally held court. Earlier, West had been influenced by performers like Bert Savoy and Julian Eltinge, the premier female impersonators of the early 1900s in vaudeville. Eltinge's act was more ladylike and based in mimicry whereas Savoy's was outrageous, and West fused elements of each, along with the banter and slang used by drag queens of the period (Hamilton 1995: 124-125, 128-129).

The humour of the drag queens in West's writing is also something of which one should be mindful, since we can see the germ of some of the humour and delivery that Mae later made her own. The most famous example is the oft-misquoted "come up and see me sometime": in She Done Him Wrong (Sherman 1933), West invites Cary Grant's character to call by with the words "why dontcha come up some time, an' see me?", as well as "you'd better come up and see me" in I'm No Angel (also starring Cary Grant; Ruggles 1933), and later the song "Come Up and See Me Sometime" (Balcerzak 2013: 30). The origin of the line can be found in The Drag, when Winnie propositions another character, saying "come up some time and I'll bake you a pan of biscuits" (Mae West, The Drag, Act II, Scene I). Jill Watts has argued that this line has its origins in Bert Savoy's campy "you must come over", an oft-repeated phrase in his drag act, reinforcing the links between West and female impersonators, who later took to adopting Mae West as a stage name (Chauncey 1994: 51; Watts 2001: 109).

Mae's use of gay performers and themes could also be interpreted as an astute move in light of the growing popularity in the early 1920s of what was termed the "pansy craze", exemplified by singers like Bruz Fletcher. Pansy singers were not dissimilar in style to West's own style inasmuch as they relied on innuendo and comic delivery of otherwise innocuous lyrics, and effectively made a joke of sex and sexuality, and ultimately of themselves. Indeed, with Mae's act as much as of the drag queens, Woman is not the joke, but perception and identity of femininity and feminine identity are (Robertson 1996: 34; Finney 2005: 67). Where West moved beyond standard representations, however, was in her choice to make the drag queens positive and even heroic characters, and showing something of their interactions and life beyond vaudeville numbers. Sex and The Drag have been frequently compared to a concurrently-running play, The Captive (translated from the French La Prisonnière, by Edouard Bourdet), about lesbianism (Bourdet 1926/2003). However, West's plays went further insomuch as The Captive never names the driving theme of the play, nor does it directly depict or speak about it, or even show one of the lesbian characters (Hamilton 1995: 71-72). Both productions were raided at the same time (Rathbone 1962/2004: 101-105; Wortis Leider 1997: 320-322).

When police got rough with drag performers being arrested - in the case of The Drag, some were taken to paddy-wagons while still in full costumes - Mae criticised the police, saying that hitting a gay man, or a man in drag, was tantamount to hitting a woman (West 1975: 40; Watts 2001: 112-113). She declared gays were women trapped in men's bodies and as such ought to be treated with a modicum of decorum, drawing on the ideas advanced by Karl Heinrich Ulrichs in the late 1800s (Schlissel 1997: 97). West was tolerant, and even supportive, of gay men, though she appeared less forgiving when it came to lesbians. It could be that she didn't understand why women couldn't love men - something she had in common with gay men. Even in this regard she downplayed the significance of her permissiveness, and couched it in terms that were less shocking at the time (West 1975: 41-43).

The other transgressive element that regularly appeared in Mae West's stage, screen and novel roles or writing was prostitution, with West regularly casting herself as a prostitute or similar figure without hesitation. One can also see the elements of the Mae West Character informed by her fascination with prostitutes - the toughness, bawdy forthright manner, and her attitude towards love that was by turns pragmatic and mercenary. By addressing topics like prostitution or drug addiction within a period setting, she could manipulate the nostalgia 
for a bygone era, and also defuse the tension at seeing criminal activity by placing it within a "different" context, such as the Bowery of the late nineteenth century (Robertson 1993: 58). This had the added effect of highlighting her behaviour which was ahead of its time even for the 1930s, and heightening the disjunction between restrictive roles faced by women and the Mae West characters' apparent freedom, even if exploiting and satirising the narrowness of her choices. To an extent, the prostitute and drag queen characters bleed into one another in West's work, particularly her plays, being flawed but good-hearted, and often recycling names and traits, for instance the drag queens Paradise and Peaches who appear in The Pleasure Man. These characters are no doubt variations on the respective heroines of Sex and the film Every Day's a Holiday (Sutherland 1937): Margy LaMont, who wears bird of paradise plumes, and Peaches O'Day.

As well as threatening the established order by playing prostitute roles, she is what Ramona Curry calls an "ironic prostitute" - that is, she poses an economic and social threat, and refuses to take her circumstances seriously, adding the disarming element of humour or satire which with West was often also quite ambiguous but indubitably placed her in control (Curry 1991: 75). When dealing with the question of control, one should remember that West learned "to use sex as a weapon. She wore her disreputability like a suit of armour, a source of protection and personal power. Just as important, she grew up supremely confident in using sex as a tool onstage" (Hamilton 1995: 16). This can be seen clearly in relation to the characters explicitly identified as sex workers, but is equally relevant to her other characters, who play on their appeal at the same time as they joke about it, and eventually emerge victorious - getting the last laugh in every sense.

In creating prostitute heroines and comparatively virtuous drag queens, West simultaneously toyed with notions of class and representation. Throughout her career she also capitalised on the sex appeal she exuded (described by director Edward Elsner as a "low sex quality"), and never lost her Brooklyn accent or working-class origins, though she claimed royal descent as well, and often linked her history to celebrities or infamous characters of the day, including Evelyn Nesbit and Harry Thaw (West 1959: 83; Eels \& Musgrove 1982: 20; Watts 2001: 4, 73). By connecting herself to scandalous or celebrated figures, she could share in their cachet, and she oscillated between downplaying her working-class origins and constructing an aristocratic, "ladylike" character. West collapsed class distinctions in her life and art, and rather than idealising or stylising poverty and prostitution, she aimed for realism by drawing on her own experiences - a prostitute whom she saw wearing bird of paradise feathers was a favourite muse - and the actual drinkers and drag queens she encountered (Eels \& Musgrove 1982: 59). It was said that to see Mae West's plays was equivalent to going slumming, bringing the street and the denizens of less reputable districts into the public eye and public spaces, evoking or recreating the spaces frequented by drag performers, homosexuals and prostitutes (Chauncey 1994: 311-312; Watts 2001: 75-76; Heap 2009: 238). In this regard, it is curious to note that a parallel has been drawn between the opening dialogue of The Drag, and pornographic films of the early 1900s. In The Drag, a doctor discusses homosexuality in earnest, and argues in favour of compassion, despite using terms that to a contemporary audience would sound offensive ("degeneracy" and "inversion" among them). Pornographic films sometimes employed a similar spiel at the beginning, to "give them redeeming social value" (Eels \& Musgrove 1982: 65).

West's physicality was another famous aspect of her public persona that was quite literally too much: exaggerated movements, over-the-top costumes and clothing, and an ample figure that she enhanced with towering platform heels and corsets that emphasised her bust, as demonstrated when she suggested to Marlene Dietrich, known for her shapely legs, "you give 'em the bottom and I'll give 'em the top!", pulling one breast out of her corset for emphasis (Riva 1994: 151-152). She was as over-the-top off-screen as on it, with her 
trademark swaggering gait (as much a result of her high shoes as her personality) and movements copied from drag queens. The fact that she had mimicked drag performers is in itself another indicator of how West went "too far", by imitating performers who themselves imitated and exaggerated certain traits, either in terms of "camping", or impersonating women. West was herself praised in Vanity Fair as "the greatest female impersonator of all time" (Watts 2001: 148). In addition to the links of impersonating women more generally, Mae West also identified with transgressive women of myth and history, and incorporated them, or performances as them into her own act, impersonating (or perhaps to her mind channelling) figures with whom she felt an affinity. This extended to her films like Goin' To Town, where she plays dance-hall artiste Cleo Borden who has a number in a Samson and Delilah duet (forming a chain of Mae-as-Cleo-as-Delilah). More prominently, West identified with Catherine the Great, to the extent that she created a stage production, Catherine Was Great, after several years of unsuccessfully trying to make a film of her idea. She also performed in a radio skit as Eve that scandalised listeners during its Sunday broadcast (Eels \& Musgrove 1982: 168; Louvish 2006: 320-323).

\section{Race and raciness ("I only like two kinds of men: domestic and imported")}

In addition to championing gay rights, Mae has been frequently upheld as a champion of civil rights because of her apparent liberal attitude where black actors were concerned. While West was not necessarily a crusader for equal rights, she did recognise the inequities around her, particularly in relation to performance. West may have been partially spurred to act in defiance of social mores by public disapproval of her own lack of prejudice, but she was more restricted in regards to the racism of the Hays Code and social attitudes than she was with her jokes. At times, she had her way, as with her film Every Day's a Holiday (Sutherland 1937), in which she was accompanied by Louis Armstrong; and when she insisted on Duke Ellington performing in Belle of the Nineties (McCarey 1934), maintaining that the sound would be of superior quality than if the studio dubbed backing tracks with white musicians (Watts 2001: 186-187; Louvish 2006: 107, 204). The choice of musicians was potentially a clever move to capitalise on his popularity as much as to strike a blow for the rights of non-white performers. Everything West did, said and wore, as well as her supporting cast, was carefully calculated to cast her in the best possible light and serve the story. Even the male leads were rendered supporting cast and played a subordinate role to the Mae West Character. This is another reason for her choice of "gay nineties" settings and costumes for her films - the use of corsetry and garments that highlighted her hourglass figure served her better than flapper fashions of the day. It also has to be noted that she never showed too much flesh. All of her costumes (with the exception of Tira's belly-dancing outfit in I'm No Angel) concealed her body while showing off her curves to best advantage. The costumes, like the dialogue, were not overt but reliant on suggestion, playing with concealment or withholding.

West frequently appropriated elements of black culture within New York and Chicago, as when she frequented black-and-tan bars, and noticed the dance called the shimmy shawobble. She claimed that she brought it into the public eye and made it famous in her own act, but this is disputed. Mae deliberately tried to shock people, following one of her oft-quoted axioms - "those who are easily shocked should be shocked more often" - and in borrowing dances or steps like the shimmy and not only performing them as a white woman, but probably embellishing as she did with her "special movements", as described by Ian Whitcombe, she crossed boundaries of race, space and class by unleashing dances and styles 
on the public in a new space and revamped form (Wortis Leider 1997: 172-173, 221; Whitcombe quoted in Southwell 2002; Louvish 2006: 73-75, 81, 83-84).

More frequently, Mae West included supporting characters who pushed the boundaries of what was possible for non-Caucasian actors, such as her maids. These women are shown as confidantes and are privy to intimate details and a hidden side of Mae's character (Robertson 1996: 50). She engages in banter and, in I'm No Angel, sings with them. The maids and West's character Tira then discuss their love lives and their ideal type of man. Some of the scenes with maids, however, contain condescending echoes and a too-rosy tint to heighten the allure of the Mae West Character, as seen in She Done Him Wrong (Sherman 1933). Here, the dialogue between Lady Lou (West) and her maid Pearl (Louise Beavers) veers from melodramatic lauding to intimate banter to condescension. Lou chit-chats and chides in equal measure, but not before Pearl declares with a grin (in stereotypical slang) that she loves working for Lou. A common feature of some of West's films is this patter between West's protagonist and her maids, yet there are patronising references to "8-ball" or "Shadow" at the same time. West cast her actual maid, Libby Taylor, in the role of her maid, allowing art and life to bleed further into one another. Taylor eventually quit working in service and established a career as an actress, although restrictions on non-white actors meant that she was limited to playing maids (Louvish 2006: 204, 133-134).

Beyond the common dynamic of mistress and maid, West frequently ruffled feathers with representations of interracial sex and marriage. Her novel, The Constant Sinner (originally published as Babe Gordon in 1930), paints a lurid picture of raw sensuality in black-and-tan bars and relationships between black men and white women. Within the story, the heroine Babe Gordon is depicted as too worldly and too great a connoisseur of men to be put off by race, linking to West's own mythicised sexual appetite and "colour-blindness" where her lovers were concerned (Hamilton 1995: 146). Though there is racial and sexual stereotyping present, it serves to highlight the moral hypocrisy of the time (Wortis Leider 1997: 495). West's more open-minded approach to race issues could easily be traced to her upbringing: her father, "Battlin' Jack" West had black friends, so Mae had always been at ease with their presence and language (Wortis Leider 1997: 21; Chandler 2009: 59-60). She also took at least one black lover, the boxer Chalky Wright, who also worked as her chauffeur (Louvish 2006: 285, 383; Chandler 2009: 218-219). Moreover, as a child Mae West, like Sophie Tucker, had performed in blackface as a "coon shouter" during her vaudeville career (Watts 2001: 22). ${ }^{1}$

Klondike Annie (Walsh 1936) touches on race relations, but follows the trope of the predatory foreigner stealing a white woman. In the film, West plays Rose Carlton, the "Frisco Doll", a former streetwalker and reluctant kept woman of the possessive Chan Lo, whom she murders in self-defence before escaping on a boat to Alaska. To evade prosecution for murder she adopts the identity of her berth-mate Sr. Annie Alden, a missionary who dies of natural causes during the voyage. Her maid, Fah Wong, effectively replaces the black maid character, and shares further intimacy with Rose when they converse in Mandarin. This kind of racial interaction would have caused controversy at the time, but it was West's perceived travesty of religion that attracted the most criticism (Louvish 2006: 294-307). Klondike Annie (Walsh 1936) has been described as lacking the punch and pacing of West's previous films, either demonstrating material that was starting to go stale or that the rules of the Motion Picture Production Code enforced by the likes of Joe Breen (a more rigid censor than his predecessor, Will Hays) had rendered the film more anodyne. Curiously, in circumstances that West herself could not have been pleased, some of the best and boldest lines in the film are given to two other female characters, who seemingly act as substitutes for the Mae West Character while West's own Rose is masquerading as a missionary and thus "atoning" for her lifestyle. $^{2}$ 
This film, however, is self-contradicting and holds back from being too transgressive. Despite Rose Carlton saying that between two evils she generally picks the one she never tried, she opts for the oft-tried alternative offered by Bull Brackett, the rough sea captain, rather than the Inspector who is willing to jeopardise his career to marry her. The conventional ending (coupled with her decision to return to San Francisco to clear her name) is most probably the result of edits to satisfy Joe Breen and "clean up" the film. It is also linked to the question of class and mobility, as with Sex, where Margy LaMont has the opportunity to make a socially advantageous marriage, but opts instead to remain single.

\section{A marvel of the age ("You're never too old to become younger")}

In terms of literally going too far, or perhaps going further than anyone else, Mae West refused to cede to time and age, and saw herself as forever youthful and alluring. Even today, when debate continues regarding age and women in Hollywood, and the filmic representation of women over forty, Mae never budged from a set of rules she clearly laid out for herself early in her career which included playing a pitiable or weak woman, a mother, or anyone over twenty-six (Louvish 2006: xi). ${ }^{3}$ When she arrived in Hollywood just shy of her fortieth birthday, she became a cinematic sex symbol alongside younger actresses like Jean Harlow, and maintained an assertive pursuit of, and interest in, sex that was seen as shocking, especially for an older woman.

Stubbornly adherent to her own rules, she was extremely particular about her working environment, the people around her and ultimately the correct means of serving the story, that is, the Mae West Character and her own public image. This self-promotion is also commonly seen to have gone too far, albeit in an entirely humourless way. When Joe Breen said that "difficulty is inherent with a Mae West picture" (Curry 1991: 64), there were others who had worked with West and shared Breen's sentiments. She was seen as too controlling in how she took credit for her own work and others, too demanding in her on-set behaviour (as far as matching her exacting standards, rather than in the sense of the contemporary diva), and eventually too risky as an investment following an article labelling her Box Office Poison (Eels \& Musgrove 1982: 190; Wortis Leider 1997: 221, 289-290; Southwell 2002). It must be admitted, however, that she did play a major role in saving Paramount from receivership, if not single-handedly bringing it back from bankruptcy as she and others have told the story (Louvish 2006: 214, 238).

In keeping with her rules, when West was offered the role of Norma Desmond, she declined, telling Billy Wilder that she was no has-been (Lally 1997: 186-189; Chandler 2009: 217). Similarly, and despite having covered Beatles songs as part of a reinvigorated career as a recording artist, she objected to her inclusion on the cover of the Beatles' Sergeant Pepper's Lonely Hearts Club Band album cover, reasoning "why would Mae West be in a Lonely Hearts Club?". She later relented, and her image is seen alongside others including Marlene Dietrich (Martin 1995: 139). She later brought out her own album, Way Out West, covering songs like "Great Balls of Fire". However, West's rules became a trap of sorts as much as a personal guide in her career. In her final two films she became a grotesque, a parody of herself (where the audience more often laughs at than with her). No longer the sole star or primary focus, Mae (who insisted on being called "Miss West" by those around her) still pushed the boundaries of taste, gender, and age but more in terms of the blurring between her onscreen character, her star power offstage, and the fact that by her eighties the "real" Mae was indistinguishable from the Mae West Character.

In Myra Breckenridge (Sarne 1970), the antics of the other characters are more shocking than any Westian innuendo. By her own admission, however, she relished the 
chance to use material that never would have been permitted during the earlier part of her film career (Louvish 2006: 404). The movie, however, was a critical failure, derided for both it style and content. West was ahead of her time as a writer in terms of content and comedy, but by the 1970s social mores and humour had effectively caught up with her. Amidst the scenes involving dream sequences, strap-on dildos and sexual assault, the witticisms that are quintessentially Mae West's pale in comparison in terms of shock value. West still had basically the same material that she had been using for decades, and despite having the potential for greater latitude with her jokes and ample opportunities to break new ground with her humour or further explore taboo material, she never moved beyond wordplay and innuendo. The closest that West ever came to outright swearing was in Sextette (Hughes 1978), when she declares "I'm the girl that works at Paramount all day and Fox all night" (again, her use of "girl" is noteworthy, when West was over 80 at the time). In actual fact, West disapproved of post-1970s film and television, with its proliferation of four-letter words, gratuitous violence and nudity. She compared censorship to corsetry: that is, a necessary restraint to pull in and push out in all the right places (Wortis Leider 1997: 18-19, 649-650). The discussion of contemporary censorship and mores also provided her with the chance to craft more quips, as she had responded to criticism of her work for violating the Hays Code, with a typically glib riposte, "I believe in censorship. After all, I made a fortune out of it" (Vogel \& Nocera 2007: 72).

The essence of Mae West's transgressiveness lies in her nature as a sexually voracious older woman, something that continues to be a problematic subject. Her perpetually active interest in sex, and her refusal to retire -or be retiring- can be both shocking and uncomfortable to watch even today, but her final two films are commonly seen as shocking and distasteful, or simply bad.

\section{Conclusion}

Mae West broke new ground in comedy and women's roles in performing, comedy or otherwise, by playing with the limits of humour and perceptions of what was too much, too little or just enough. Indeed, if not for her, films presenting sexual taboos like Myra Breckenridge (Sarne 1970) would not exist, nor would bawdy, irreverent performers like Bette Midler and stand-up comedians such as Phyllis Diller with her self-parody and rapidfire delivery, as well as Joan Rivers' constant confrontation of taboos or Jackie "Moms" Mabley's doubly subversive stand-up addressing sexuality and age. Despite not really fulfilling the prevailing notions of conventional female sexuality or conforming to models of femininity, West became a sex symbol. She fused the parodic acts of Bert Williams, Eva Tanguay and others, challenging class, race and gentility. She opened doors for female performers in ways hitherto unimagined, and inspired generations of performers across genres and media.

In going too far for her age, Mae West created her own style of comedy that has inspired subsequent generations to go progressively further. West's oeuvre and style perfectly embodied two sayings commonly attributed to her: too much is still too much, but too much of a good thing can be wonderful.

\section{Notes}

1 The "coon shouter" was a common character based on racist stereotypes of AfricanAmericans during the late nineteenth and early twentieth centuries, often played by white 
women in sketches and songs. It should also be noted that blackface makeup was also compulsory for Africa-American performers, such as Bert Williams.

${ }^{2}$ Oddly, in Klondike Annie, there are effectively three Mae West-type characters: Mae as Rose/Sister Annie, Lucille Gleason as Big Tess (a former colleague), and Esther Howard as the dance-hall owner Fanny Radler, who quips about Rose/Sister Annie to the other dancehall girls "She may sing hymns but don't tell me she don't know plenty of other tunes".

${ }^{3}$ The Prologue of Simon Louvish's biography of West reproduces an undated list of "Things I'll Never Do", on which is included a refusal to play "mother parts, sad parts, dumb parts, or a virtuous wife" (Louvish 2006: xi).

\section{Film and Television References}

Cline, E.F., dir. (1940). My Little Chickadee. Universal Pictures.

Hall, A., dir. (1935). Goin' To Town. Paramount Pictures.

Hughes, K., dir. (1978). Sextette. Crown International Pictures.

Mayo, A., dir. (1932). Night after Night. Paramount Pictures.

McCarey, L., dir. (1934). Belle of the Nineties. Paramount Pictures.

Ruggles, W., dir. (1933). I'm No Angel. Paramount Pictures.

Sarne, M., dir. (1970). Myra Breckenridge. $20^{\text {th }}$ Century Fox.

Sherman, L., dir. (1933). She Done Him Wrong. Paramount Pictures.

Southwell, B., dir. (2002). Living Famously: Mae West. Bristol: BBC Bristol.

Sutherland, A.E., dir. (1937). Every Day's A Holiday. Paramount Pictures.

Walsh, R., dir. (1936). Klondike Annie. Paramount Pictures.

\section{Print References}

Ashby, L. (2006). With Amusement For All: A History of American Popular Culture Since 1830. Lexington KT: University Press of Kentucky.

Balcerzak, S. (2013). Buffoon Men: Classic Hollywood Comedians and Queered Masculinity. Detroit: Wayne State University Press.

Bourdet, E. (1926/2003). 'The Captive', in Hodges, B. (ed.), Forbidden Acts: Pioneering Gay \& Lesbian Plays of the Twentieth Century, New York: Applause Theatre \& Cinema Books, pp.83-171.

Butler, J. (1990, 1999). Gender Trouble. New York: Routledge.

Carmichael, R. and Nuttall, J. (1992). Common Factors-Vulgar Factions. London: Routledge.

Chandler, C. (2009). Mae West: She Always Knew How. New York: Simon \& Schuster.

Chauncey, G. (1994). Gay New York. New York: Basic Books.

Curry, R. (1991). 'Mae West as Censored Commodity'. Cinema Journal 31 (1), pp. 57-84.

Failler, A. (2005). 'Excitable Speech: Judith Butler, Mae West and Sexual Innuendo", in Sönser Breen, M. and Blumenfeld, W.J. (eds.), Butler Matters, Aldershot: Ashgate, pp.95109.

Glenn, S. (2000). Female Spectacle: the Theatrical Roots of Modern Feminism. Cambridge Mass.: Harvard University Press.

Hamilton, M. (1992). 'Mae West Live: SEX, The Drag and 1920s Broadway'. Tulane Drama Review 36 (4), pp. 82-100. 
Hamilton, M. (1995). The Queen of Camp: Mae West, Sex and Popular Culture. London: HarperCollins.

Heap, C. (2009). Slumming: Sexual and Racial Encounters in American Nightlife, 1885-1940. Chicago: University of Chicago Press.

Lally, K. (1996). Wilder Times: The Life of Billy Wilder. New York: Henry Holt.

Louvish, S. (2006). Mae West: It Ain't No Sin. London: Faber and Faber.

Macqueen-Pope, Walter. (1957/2010). Queen of the Music Halls: Being the Dramatized Story of Marie Lloyd. London: Nabu Press.

Martin, G. (1995). Summer of Love: The Making of Sergeant Pepper. London: Macmillan.

Merryman, R. (1969). 'Mae West'. Life Magazine, 18 April, pp. 60-73.

Rathbone, B. (1962/2004). In and Out of Character. New York: Doubleday.

Riva, M. (1994). Marlene Dietrich, by her Daughter. London: Hodder \& Stoughton.

Robertson, P. (1993). "'The Kinda Comedy That Imitates Me": Mae West's Identification with the Feminist Camp'. Cinema Journal 32 (2), pp. 57-72.

Robertson, P. (1996). Guilty Pleasures: Feminist Camp from Mae West to Madonna. Durham, London: Duke University Press.

Schlissel, L. (ed.) (1997). Three Plays by Mae West. London: Nick Hern Books.

Troy, W. (1933). 'Mae West and the Classic Tradition'. Nation Review, 8 November, pp. 547-548.

Vogel, M. and Nocera, L. (2007). Hollywood Blondes: Golden Girls of the Silver Screen. Shelbyville: Wasteland Press.

Watts, J. (2001). Mae West: An Icon in Black and White. Oxford; New York: Oxford University Press.

West, M. (1975). Mae West on Sex, Health and ESP. London: W.H. Allen.

Wortis Leider, E. (1997). Becoming Mae West. New York City: Da Capo Press. 